\title{
The Influence of Socio-Economic Inequality on Educational Outcome: A Comparison of Turkana County and Kiambu County- Kenya
}

\author{
Samuel Ronguno* Paul Ejore \\ School of Education, Kotalel Samoei University College, P.O Box 5, Mosoriot, Kenya
}

\begin{abstract}
The study was carried to determine how poverty influence educational outcome in Turkana County, establish major causes of poverty in Turkana County and assess poverty alleviation mechanisms advanced by the government. Data was collected by use of structured questionnaire, interview guide, focused group discussions and documentary analysis. The focus was on performance in Kenya Certificate of Secondary Education in Turkana County (with $87.5 \%$ poverty incidence) in comparison with Kiambu County (with $24.2 \%$ poverty incidence). The findings of the study revealed that poverty has adversely affected educational outcome in Turkana County while Kiambu County perform well. The cause of poverty in Turkana County is attributed to erratic weather, long droughts, insecurity and inadequate development.
\end{abstract}

Keywords: Poverty, Socioeconomic Inequality, Educational Outcome

DOI: 10.7176/JEP/10-24-07

Publication date: August 31st 2019

\section{Introduction}

\subsection{Background}

Kenya is a country characterized with variance from its landscape, demographics, educational outcomes, economic viability and so on. It is one of the most unequal countries, more so in its social and economic entities. Large segments of the population live in extreme poverty. They are highly vulnerable to climatic, economic and social shocks. Educational outcomes seem to be a reflection of the economic status of the citizens. Over the years, performance in the Kenya Certificate of Secondary Education (KCSE) results and that of Kenya Certificate of Primary Education( KCPE ) have always portrayed a skewed trend in favor of schools located in either major towns or agriculturally viable regions. Generally, analysis reveals that schools that perform well are those located in areas considered economically well-off. Under the Jubilee Government, one of the things that Kenyans are proud of is the introduction of free day secondary education and partially free boarding secondary education. The aim of the government was to ensure equitable access to quality secondary education by all Kenyan children exiting primary education. Formal education as it is known would naturally serve as a channel through which many learners who perform well would exit poverty. However, over five years down the line, there is no change in the trend of educational outcome, signaling still a pessimistic future for the children with poor backgrounds. This study sort to determine the influence of socioeconomic inequality on educational outcome. Statistics has shown that Turkana is one of the poorest counties in Kenya while Nairobi and Kiambu are the wealthiest counties.

The Economic Survey Report (2014) indicates that a county with a high population of poor people contributes immensely to the national poverty index. The report states that the contribution to the national poverty indicator is defined as the number of poor people in a county expressed as a percentage of the total number of people in the country. The indicator is more sensitive to population than to poverty incidence in a given area. "A county with a high population and low poverty incidence may have a higher contribution to national poverty than one with less population even if it has a high poverty incidence," reads part of the report.

Table 1: Top five counties contributing highest poverty index

\begin{tabular}{|l|l|l|l|}
\hline County & Population & Population percentage nationally & Poverty index ( \% ) \\
\hline Kakamega & $1.64 \mathrm{M}$ & $4.1 \%$ & 4.77 \\
\hline Mandera & 927,605 & $2.4 \%$ & 4.69 \\
\hline Turkana & 801,346 & $2.1 \%$ & 4.13 \\
\hline Nairobi & $3.06 \mathrm{M}$ & $7.9 \%$ & 3.94 \\
\hline Bungoma & $1.35 \mathrm{M}$ & $3.5 \%$ & 3.79 \\
\hline Total & $\mathbf{7 , 7 7 8 , 9 5 1}$ & $\mathbf{2 0 . 0} \%$ & $\mathbf{2 1 . 3 2} \%$ \\
\hline
\end{tabular}

According to the figures provided in table one and in accordance with the total national population of 38.6 million people ( KPHC 2009), approximately $20 \%$ of the population of Kenya live in the top five counties in terms of poverty index and they contribute about $21.32 \%$ poverty index. 
Table 2: Bottom five counties (contributing the lowest poverty index)

\begin{tabular}{|l|l|l|l|}
\hline County & Population & Population percentage nationally & Poverty index ( \%) \\
\hline Lamu & 101539 & $0.26 \%$ & $0.73 \%$ \\
\hline Isiolo & 143294 & $0.37 \%$ & $0.73 \%$ \\
\hline Kirinyaga & 528054 & $1.37 \%$ & $0.79 \%$ \\
\hline Taita Taveta & 152103 & $0.38 \%$ & $0.82 \%$ \\
\hline Tharaka Nithi & 365330 & $0.90 \%$ & $0.87 \%$ \\
\hline Total & $\mathbf{1 2 9 0 3 2 0}$ & $3.28 \%$ & $\mathbf{3 . 9 4} \%$ \\
\hline
\end{tabular}

From the foregoing, $3.28 \%$ of the population reside in the bottom five counties contributing the lowest poverty index and they contribute poverty index of $3.94 \%$.

A new study by the Kenya National Bureau of Statistics (KNBS) has shown that Nairobi and Kiambu Counties host the highest number of rich people living in Kenya. The two counties have a poverty incidence rate of 21.8 percent for Nairobi and 24.2 percent for Kiambu, which is significantly low compared to that of Turkana which has the highest number of poor people at 87.5 per cent. At the county level, Embakasi West emerged as the constituency with the richest residents with a poverty incidence rate of 10.2 percent while the poorest constituency was Turkana East with a poverty incidence rate of 93.1 percent.

The richest ward was found to be Lower Savannah in Embakasi East with a poverty incidence rate of 3.3 per cent while in Katilia Ward in Turkana, almost everyone is poor as the poverty incidence rate leads at 98.9 per cent. Table three provides counties with the lowest five and the highest five poverty incident rates.

Table 3: Lowest and Highest poverty incidence

\begin{tabular}{|l|c|l|l|}
\hline Counties with lowest poverty incidence rate & \multicolumn{2}{l|}{ Counties with highest poverty incidence rate } \\
\hline County & Poverty incidence rate & County & Poverty incidence rate \\
\hline Nairobi & $21.8 \%$ & Turkana & $87.5 \%$ \\
\hline Kiambu & $24.2 \%$ & Wajir & $62.6 \%$ \\
\hline Kirinyaga & $22.3 \%$ & Marsabit & $63.7 \%$ \\
\hline Nyeri & $19.2 \%$ & Tana River & $62.2 \%$ \\
\hline Meru & $19.1 \%$ & West Pokot & $57.4 \%$ \\
\hline
\end{tabular}

The table indicates that poverty incidences per county ranged from a low of 21.8 per cent in Nairobi to a high of 87.5 in Turkana. This implies that two in every 10 people in Nairobi live below poverty line compared to nine in every 10 people living in Turkana County. Additionally, poverty rate in Nairobi is approximately half the national average - 45.2 percent, while Turkana has almost double the national poverty incidence. The results also show that Wajir and Mandera in Northern Kenya have high poverty incidences of above 80 per cent while those with low poverty rates of below 30 percent are Kiambu, Kirinyaga and Nyeri counties. For purposes of better understanding, it may be good to know a few basic facts about the two counties; Turkana and Kiambu.

\subsubsection{TURKANA COUNTY}

Turkana County is located in the former Rift Valley Province of Kenya. It is the second largest county in Kenya with a total area of $68,680 \mathrm{~km}^{2}(26,520 \mathrm{sq}$ miles)-including the area covered by lake Turkana. It is the northwestern most county in Kenya. It is bordered by the countries of Uganda to the west; South Sudan and Ethiopia. Neighboring counties (in Kenya) are West Pokot, Baringo, Samburu and Marsabit. The headquarter and largest town is Lodwar.

\subsubsection{ECONOMY OF TURKANA COUNTY}

Turkana is the poorest region in Kenya. The larger part of it is an arid land. The picture below gives an over view of how the better part of Turkana county looks like climatically. 


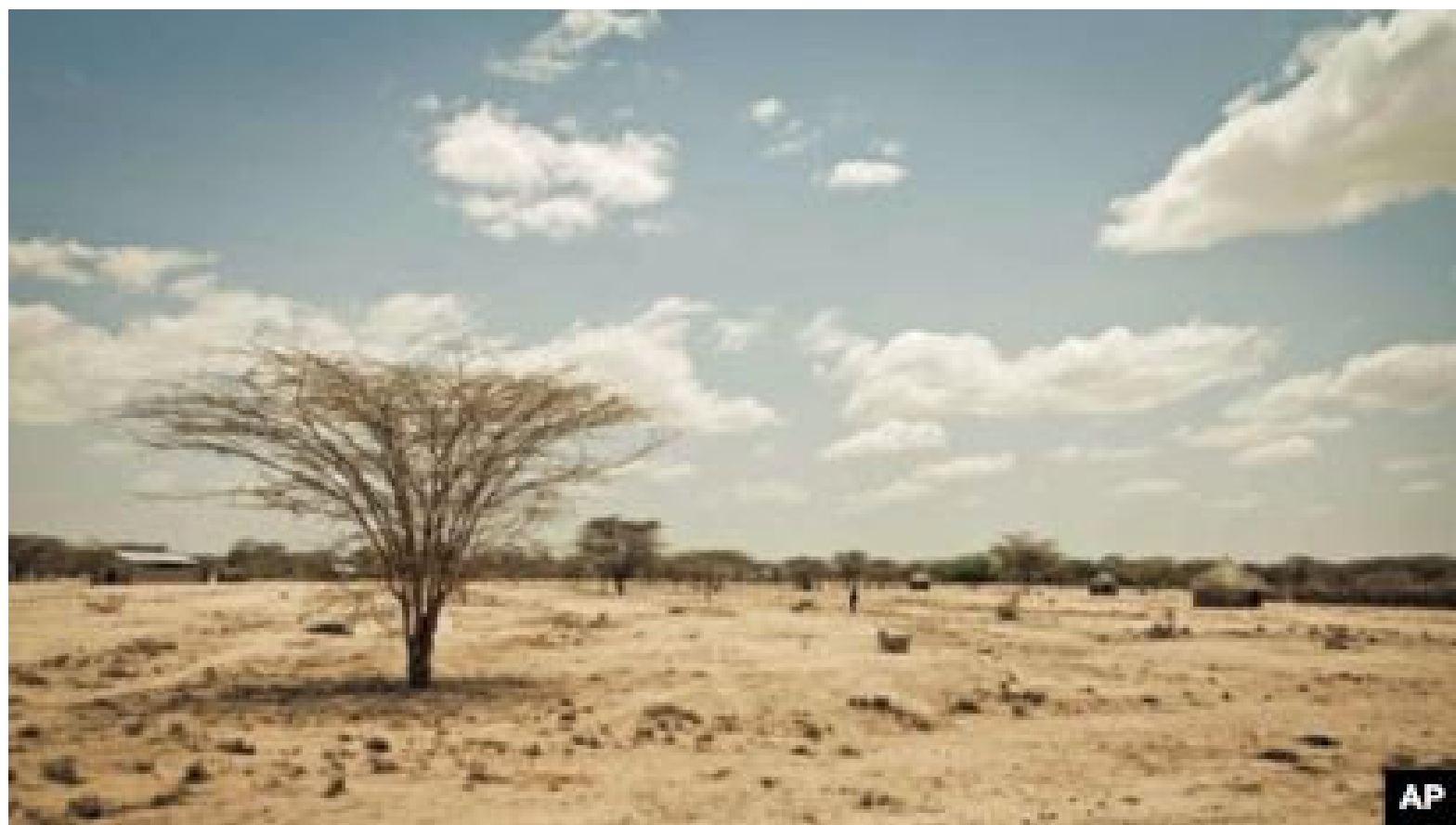

The climate of Turkana County - Kenya ( photo : courtesy of standard media group)

The main economic activity and source of livelihood in Turkana County is livestock rearing ( cows, goats and camels ). It is a flourishing source of livelihood, specially during wet seasons

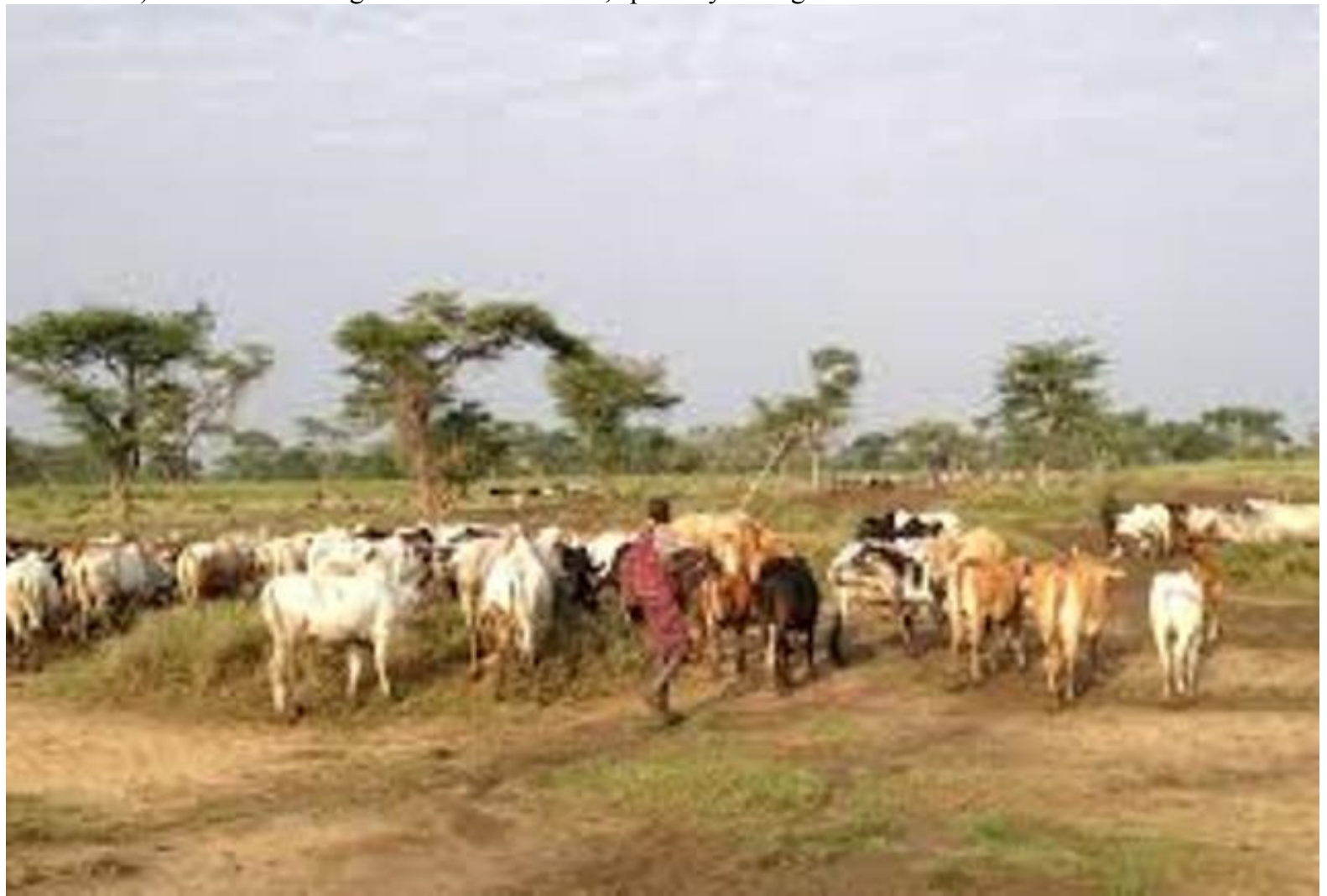

Fig. 1 Cattle herding in Turkana County ( photo : courtesy of standard media group )

The livestock look health and strong but wet seasons are usually short-lived. The larger but of the year experience dry season. Due to erratic and long droughts, the practice has been regressing over time. Thousands of livestock are lost each year due to long droughts, lack of pasture and water. The picture below shows the reality during the long droughts. 


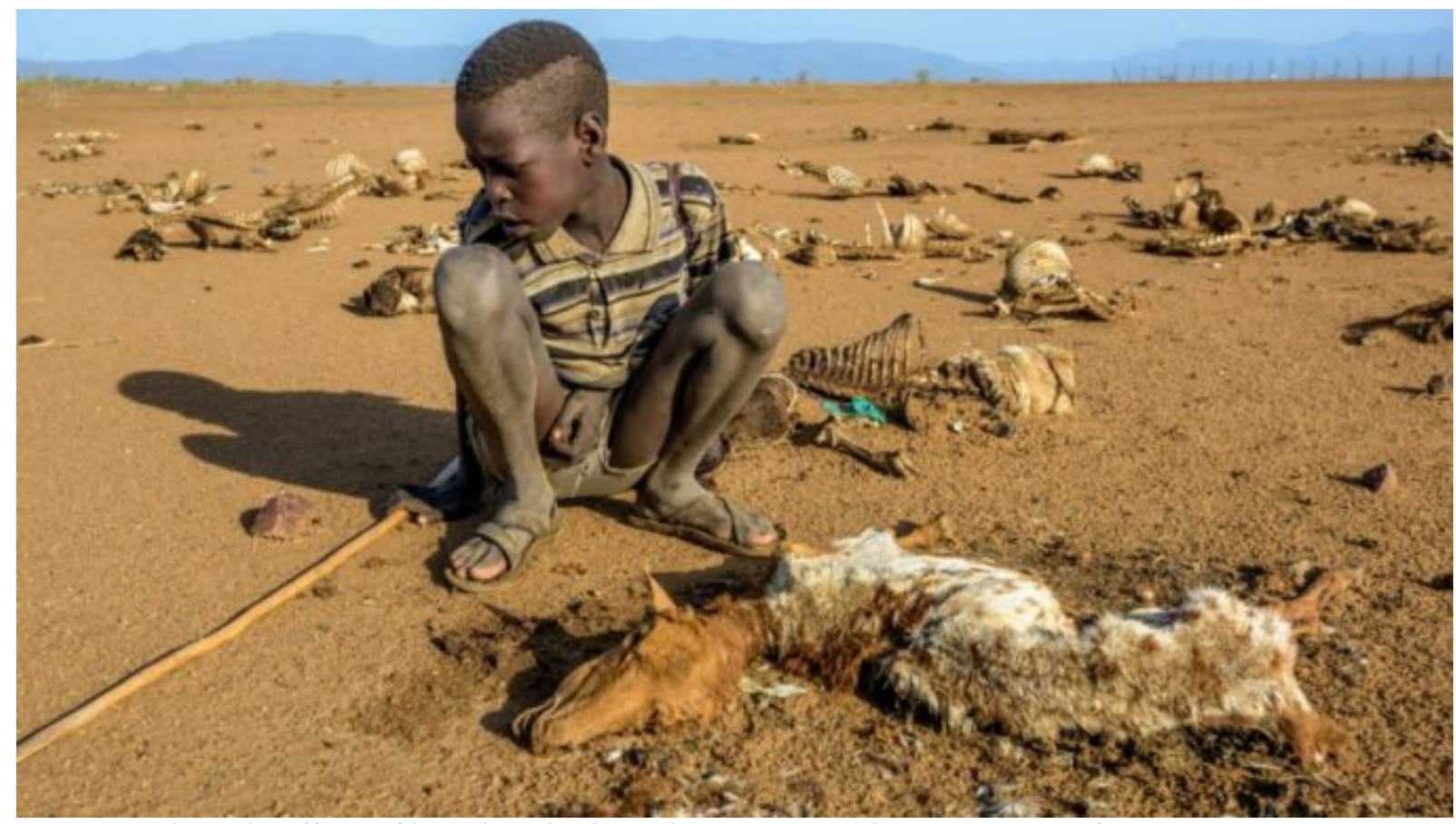

Fig.2 The effects of long droughts in Turkana County ( photo : courtesy of KARI -Kenya )

From the figure above, it is clear that the effect of long droughts and lack of water has caused serious devastations on the lives of Turkana people. Many children drop out of school to assist their parents in search of pasture and water for their livestock. None the less, the county is experiencing progressive development brought about by devolution and mineral explorations and inventions, especially of oil and water resources.

The second most reliable economic activity in Turkana County is fishing in Lake Turkana. The photograph below shows fishing at the shores of Lake Turkana.

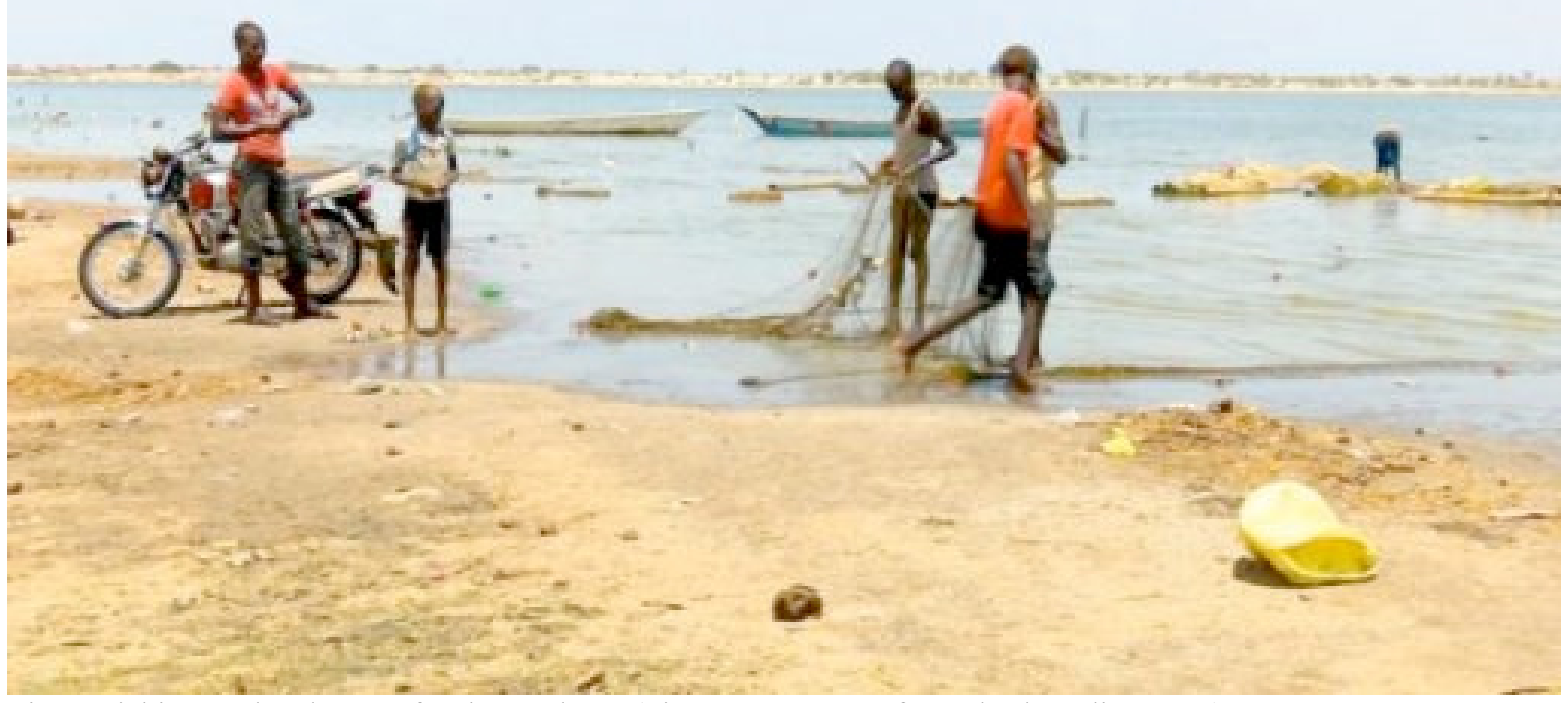

Fig. 3 Fishing at the shores of Lake Turkana (picture courtesy of standard media group)

Lake Turkana is one of the rich sources of very nutritious fish in Kenya. The fishing is an economic activity but due to lack of appropriate equipment, the local community are unable to maximize their income from fishing. Most of the local fishers use canoes and small boats within the shores of the lake. Even with the little they get, accessing market is another problem. Their fetch are sold within and so fetch very little money, just for basic needs. As a result, they remain poor. Fishing in the deep waters has been dominated by private companies-who are able to afford modern fishing equipment for deep waters and are financially able to access markets in the big towns. 


\subsubsection{INFRASTRACTURE}

According to Turkana County Annual Development Plan 2019/2020, the county has a road network measuring approximately $9000 \mathrm{~km}$, of which only $300 \mathrm{~km}$ is under bitumen though in dilapidate state while the rest is under gravel and earth surface ( E. mail : infrastructure@turkana.go.ke ).

\subsubsection{EDUCATION}

Turkana County has 197 public primary schools and 19 public secondary schools, summing up to a total of 216 public schools in the county. In addition, it is hosting 23 private secondary schools. In total, the county has 42 schools offering secondary education. Simple arithmetic shows that each of the public secondary schools serves an average area of 3,615 sq km. Although most of the private secondary schools are located near the main towns, both public and private secondary schools combined, translates to one secondary school serving an average area of $1635 \mathrm{sq} \mathrm{km}$. Performance in Kenya Certificate of Secondary Education (KCSE) have not been very good. The following is a list of top five secondary schools in KCSE of 2018.

Table 4: Turkana County: Top five secondary schools in KCSE 2018

\begin{tabular}{|l|l|l|l|l|}
\hline Position & School & No. of students & Mean Grade & No. of As \\
\hline 1 & Limyounsim Sec & 24 & 7.125 & 0 \\
\hline 2 & Turkana Girls H.S & 119 & 6.458 & 0 \\
\hline 3 & Lodwar H.S & 172 & 5.699 & 0 \\
\hline 4 & Katilu Boys Sec & 105 & 5.631 & 0 \\
\hline 5 & Uhuru Girls H.S & 110 & 4.476 & 0 \\
\hline & Total & 359 & Average grade $=5.95$ & 0 \\
\hline
\end{tabular}

Source: Turkana County Education Office

The highest mean grade a student can score in KCSE is grade A. Unfortunately, none of the candidates from Turkana County managed to score it in 2018 and even in the years before. The highest mean grade scored was A(minus) by two candidates- from Limyounsin Seconday and Turkana Girls High School. The two grades attracted celebrations and a lot of praises. Further analysis of KCSE 2017-2018, showed that majority of the students failed in the examination. Below is a summary of the grades scored

Table 5: Performance Summary for 2017 and 2018

\begin{tabular}{|l|l|l|l|l|l|l|l|l|l|l|l|l|l|l|}
\hline Year & Entry/Grade & A & A- & B+ & B & B- & C + & C & C- & D+ & D & D- & E & X \\
\hline 2018 & 3275 & 0 & 2 & 15 & 36 & 71 & 103 & 186 & 308 & 507 & 899 & 1003 & 125 & 16 \\
\hline 2017 & 2937 & 0 & 4 & 13 & 33 & 51 & 79 & 165 & 360 & 680 & 925 & 119 & 16 & 0 \\
\hline
\end{tabular}

The numbers indicate that in 2018, only $227(7 \%)$ students scored $\mathrm{C}+$ and above and therefore qualified for university intake. In 2017, only $180(6 \%)$ qualified for university intake. Grade D+ is considered pass mark. It therefore means that in $2018,1228(37.5 \%$ ) passed the examination while $2047(62.50 \%)$ failed. In 2017 , the pass rate was $47.12 \%$ (1385) while 1552 (52.88\%) failed. In 2018, 16 (X) students dropped out of school before sitting for the KCSE at the end of the year. The trend in KCSE performance in the county was low all-along. Provided in Table six is the mean scores for the best 12 schools during the period 2015-1018. These are the schools that managed to get a mean-score of at least four and above. The rest of the schools had mean-scores below four Table 6: Turkana County best schools in KCSE during the period 2015-2018

\begin{tabular}{|l|l|l|l|l|l|l|l|}
\hline No & Type & Entry (2018) & \multicolumn{2}{|l|}{ KCSE Mean grades } \\
\cline { 5 - 8 } & & & & 2018 & 2017 & 2016 & 2015 \\
\hline 1 & Lodwar High Sch. & Public & 172 & 5.70 & 6.09 & 6.79 & 8.30 \\
\hline 2 & Turkana Girls H.S & Public & 119 & 6.46 & 6.06 & 6.20 & 8.20 \\
\hline 3 & Limyounsim & Public & 24 & 7.13 & 5.28 & New & New \\
\hline 4 & Katilu Boys Sec & Public & 105 & 5.63 & 4.2 & 4.68 & 6.72 \\
\hline 5 & ST Leos-Kakuma & Public & 133 & 3.82 & 4.18 & 3.62 & 6.02 \\
\hline 6 & Uhuru Girls H.S & Public & 110 & 4.48 & 4.08 & 4.62 & 3.57 \\
\hline 7 & Our Lady's & Public & 113 & 3.98 & 3.88 & 4.52 & 6.45 \\
\hline 8 & AGC Lokichar & Public & 105 & 4.20 & 3.71 & 4.16 & 4.87 \\
\hline 9 & Kainuk Mixed & Public & 148 & 2.18 & 3.33 & 4.00 & 5.78 \\
\hline 10 & Katilu Girls H.S & Public & 97 & 3.34 & 3.27 & 3.29 & 4.92 \\
\hline 11 & AIC Kangitit & Public & 89 & 3.24 & 3.12 & 2.88 & 5.02 \\
\hline 12 & Lokitaung Boys & Public & 74 & 3.27 & 3.08 & 3.22 & 4.18 \\
\hline
\end{tabular}

\section{Source : Turkana County Education Office}

The schools provided in the table above are not arranged in any specific merit or order but they are best forming schools in the entire county of Turkana. The Education office further computed the overall county KCSE mean-scores (for both private and public schools) and they were as follows: 2018 ( 3.209), 2017 ( 3.032 ), 2016 $(4,569)$ and 2015 (5.765). Majority of the education officers and heads of schools who were interviewed, reported that the county experience shortage of teachers. According to Teachers Service Commission (TSC), Turkana 
County falls fourth in the list of Counties most affected by shortage of teachers. However, Lodwar Boys High School; - one of the best secondary school in the county had an enrolment of 513 students in 2018 but could not produce an A grade in KCSE despite having 24 teachers in that year.

\subsection{KIAMBU COUNTY}

Kiambu County is located in the former Central Province of Kenya. Its capital is Kiambu and its largest town is Thika. The county is $40 \%$ rural and $60 \%$ urban owing to Nairobi's consistent growth Northwards. Kiambu County Cover an area of 2,543.42 square kilometers. It is also considered one of the wealthiest counties in Kenya. It is a leading innovative commercial hub that shares its borders with five other counties; Nakuru and Kajiado to the West, Murang'a and Nyandarua to the North and Nairobi to the South.

According to the Kenya National Bureau of Statistics report of 2009, the county had a total population of $1,623,282$. As at 2009, the population density was 638 persons per sq $\mathrm{km}$. Most people living here are predominantly farmers growing tea and coffee as cash crops alongside food crops such as maize, beans, assorted vegetables and sweet potatoes. The county enjoys a warm climate with temperatures ranging between $12^{\circ} \mathrm{C}$ and $18.7^{\circ} \mathrm{C}$. The rainfall aggregate for the county is $1000 \mathrm{~mm}$ each year.

\subsubsection{Economy of Kiambu County}

Farming and business are the main economic activities. The cool climate and consistent reliable rainfall makes it conducive for farming. June and July rank as the coldest months while January-March and September-October are the hottest months. The main commercial farming is growing of tea and coffee. The county is adjacent to Nairobi City which is also the capital city of Kenya. Thika is the largest town in Kiambu County and also the industrial hub of Kenya. As such, the county relies mostly on agriculture and industries to sustain its economy. The picture below provides a general overview of agricultural activities in Kiambu County.

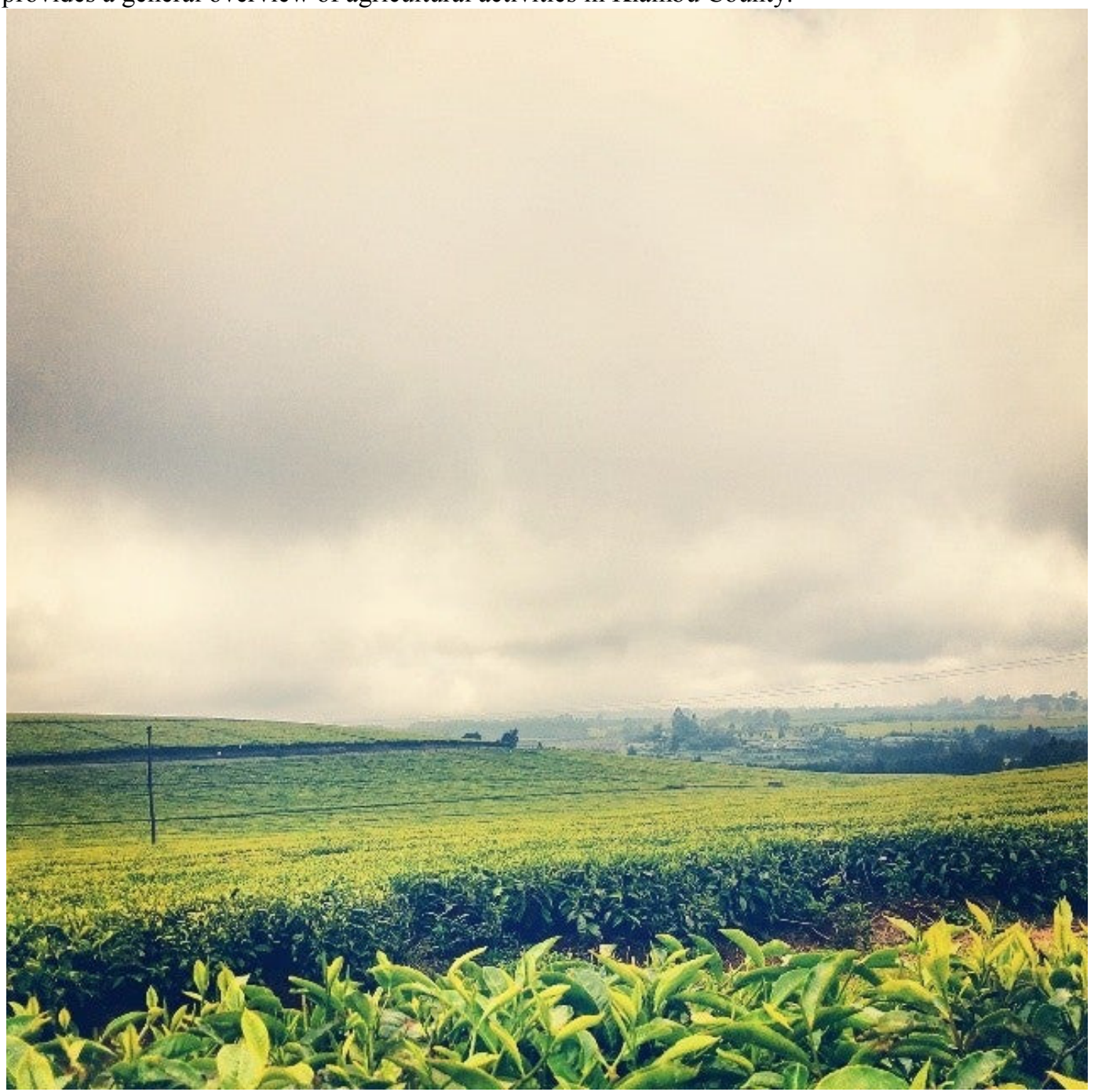

Fig. 4 Tea farming in Kiambu County - Kenya

Figure is aerial view of some commercial agricultural activities in Kiambu County. Apart from commercial 
farming, Trade and industrial activities are other sources of wealth in Kiambu County. As stated earlier, the main commercial and largest town is Thika. Below is an aerial snap photograph of Thika town.

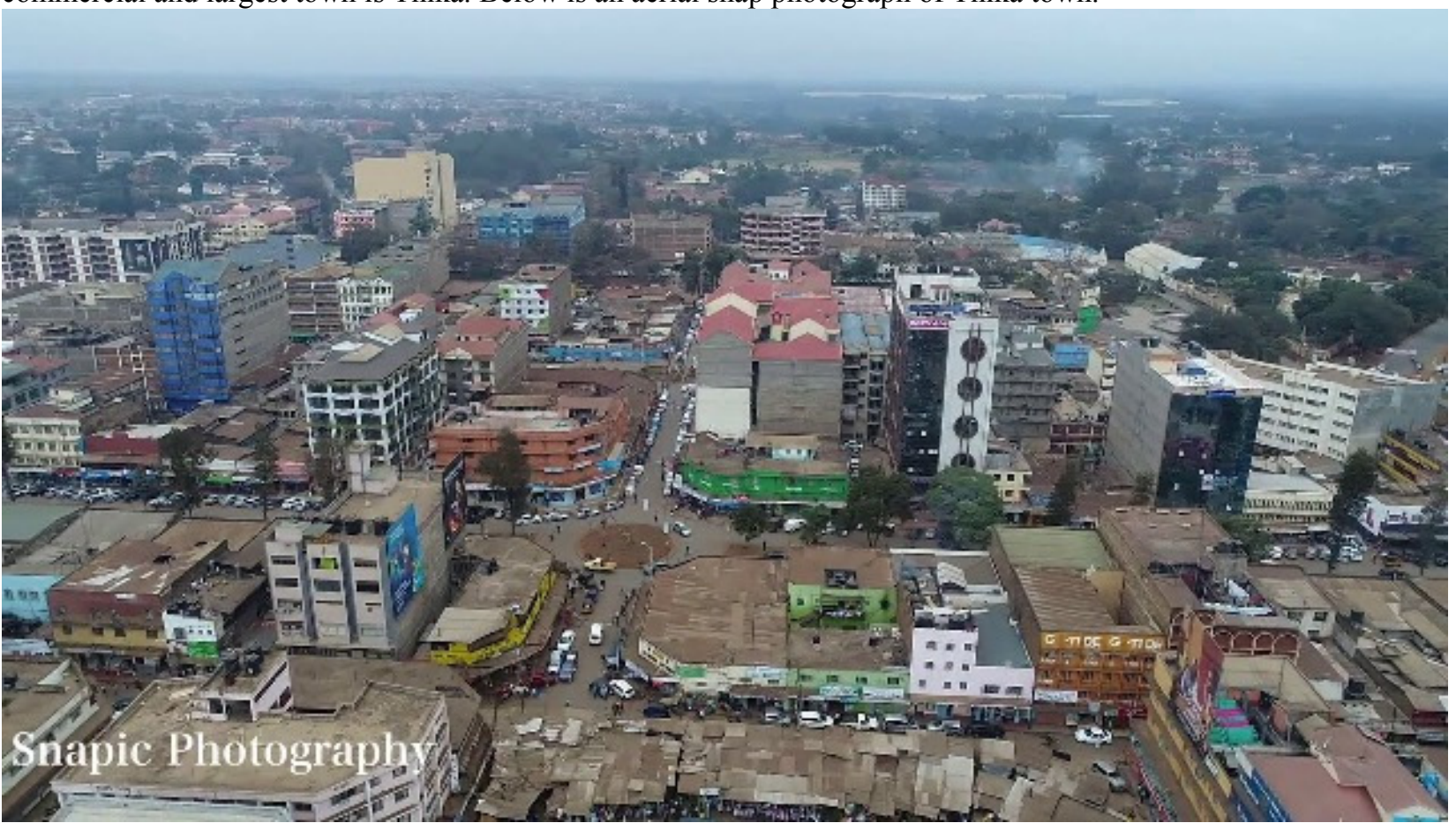

Fig. 5 Aerial view of Thika town (photo : courtesy of standard media group )

The figure above is aerial view of central business district in Thika Town. Statistics reveal that Kiambu County is the richest county outside the city. As stated before, the main sources of income are commercial activities-both agriculture and trade.

\subsubsection{Education}

The county hosts a number of middle level institutions of learning and a number of universities. The universities include Mount Kenya University, Kenyatta University, Jomo Kenyatta University of Science and Technology; Juja, Gretsa University, St Paul's university, Presbyterian University and Kiriri Women's University Of Science and Technology.

The County has a total of 1373 schools (1045 primary and 328 secondary schools ), all spread within an area of $2543.4 \mathrm{sq} \mathrm{km}$. In average, one secondary school serves an area of about $7.75 \mathrm{sq} \mathrm{km}$. Table five gives a list of top five schools in KCSE 2018 in the county

Table 7: Kiambu County Top Five secondary schools in KCSE 2018

\begin{tabular}{|l|l|l|l|l|}
\hline Position & School & No. of students & Mean Grade & No. of As \\
\hline 1 & Alliance Girls H. Sch & 199 & 9.50 & 54 \\
\hline 2 & Mangu High School & 201 & 9.00 & 35 \\
\hline 3 & Limuru Girls High Sch & 191 & 8.50 & 12 \\
\hline 4 & Kiambu High School & 158 & 8.50 & 8 \\
\hline 5 & Kagwe Girls Sec. Sch & 104 & 8.50 & 2 \\
\hline & Total & 853 & Mean Grade $=8.80$ & 111 \\
\hline
\end{tabular}

The performance displayed above is quiet impressive compared to performance of top five schools in other counties. Three among the top five schools featured among top ten schools nationally. Table seven provides the list of top ten schools nationally. While no candidate scored a mean grade of A in Turkana County, at least 111 $(13 \%)$ in Kiambu County were able to score it. 


\subsubsection{National ranking of KCSE 2018}

Table 8: Top Ten Best Schools Nationally - 2018 KCSE Results

\begin{tabular}{|l|l|l|l|l|l|}
\hline Position & School & Category & No. of Students & Performance Index & County \\
\hline 1 & Strathmore Sec. School & Private & 84 & 72.28 & Nairobi \\
\hline 2 & Moi High Sch. Kabarak & Private & 330 & 72.12 & Nakuru \\
\hline 3 & Moi Tea Girls Sec. Sch & Extra County & 136 & 69.59 & Kericho \\
\hline 4 & Alliance Girls H. School & National & 396 & 69.48 & Kiambu \\
\hline 5 & Alliance High School & National & 399 & 69.25 & Kiambu \\
\hline 6 & Mang'u High School & National & 330 & 69.11 & Kiambu \\
\hline 7 & Kisima Mixed Sec. Sch & Private & 39 & 68.37 & Nyandarua \\
\hline 9 & Precious Blood Riruta & Extra county & 161 & 67.87 & Nairobi \\
\hline 10 & Orero Boys Sec. School & Extra County & 283 & 67.78 & Homa Bay \\
\hline & The Kenya High School & National & 302 & 67.21 & Nairobi \\
\hline
\end{tabular}

From table eight, out of top ten schools in $2018 \mathrm{KCSE}$, four of them are in Kiambu county. An analysis of the results nationally, highlighted the inequality in education standards. Schools in poverty regions performed poorly compared to those in wealth regions. This has been the trend over years. For example, in the KCSE 2015, top schools in some of the counties with low poverty incidence and some of those with high poverty incidences are provided in table nine.

Table 9: Top schools in some of the counties

\begin{tabular}{|l|l|l|l|l|l|}
\hline \multicolumn{2}{|l|}{ Schools in low poverty incidence counties } & \multicolumn{3}{l|}{ Schools in high poverty incidence counties } \\
\hline School & County & Mean grade & School & County & Mean grade \\
\hline Alliance H.S & Kiambu & 11.35 & Lodwar Boys H.S & Turkana & 8.30 \\
\hline Karima Girls H.S & Nyandarua & 10.71 & Kwale H.S & Kwale & 7.84 \\
\hline Murang'a H.S & Muramg'a & 10.74 & Mandera Sec. Sch. & Mandera & 7.23 \\
\hline Moi Girls H.S Eld & U/Gishu & 10.03 & Mpeketoni Sec & Lamu & 6.76 \\
\hline Kabarak H. S & Nakuru & 11.66 & Mau Mau M. Girls & Tana River & 4.42 \\
\hline Kapsabet Boys H. & Nandi & 11.16 & Wajir H.Sch & Wajir & 6.56 \\
\hline
\end{tabular}

Table nine provides samples of schools in low poverty incidence counties and samples of schools in high poverty incidence counties and their performance. If the top school in a county had a mean grade of less than five, for example Mau Mau Memorial Girls High School -Tana River County, then how miserable could be the performance of the rest of the schools in that county?

Similarly, a comparison of Turkana County and Kiambu County (as for our case in this study ) shows a lot of disparities. The differences in levels of poverty and educational outcome is a true reflection of the differences between counties in dry parts of the country and those in the agriculturally conducive climates. It is a clear indication that educational outcome is directly proportional to economic status.

\subsection{Statement of the Problem}

The government launched free primary education in 2002 and free secondary education in 2013. The aim was to remove any possible obstacles on the path of education and ensure that no Kenyan child is disadvantaged in any way from getting basic education as a right and for self development. In 2018, the government carried out a serious campaign aimed at ensuring $100 \%$ transition from primary to secondary education. The government spends billions of money in supporting education. This includes payment of teachers salaries, purchase of instructional materials and payment of examination fees for candidates sitting for national examinations at grade eight (standard 8) and form four. Despite all these efforts, the transition from primary to secondary in Turkana County was $17.7 \%$ in 2018, though the study established that it was an improvement compared to the past. In the Kenya Certificate of Secondary Education of 2018, no candidate from Turkana County managed to score the anticipated A grade. The current study was carried out to establish the influence of socioeconomic inequality on educational outcomewith a focus on Turkana County.

\subsection{Purpose of the Study}

The study was carried to determine the relationship between socioeconomic factors and education- with focus to Turkana County and Kiambu County, establish major causes of poverty in Turkana County and assess poverty alleviation mechanisms advanced by the government.

\subsection{Research Objectives}

The study was carried out to ;

(i) determine how poverty influence educational outcome in Turkana County, 
(ii ) establish major causes of poverty in Turkana County, and

(iii) assess poverty alleviation mechanisms advanced by the government.

\subsection{Research questions}

(i) What is the relationship between poverty and educational outcome in Turkana County?

(ii) What are the main causes of poverty in Turkana County?

(iii) What are the mechanisms put in place to alleviate poverty in Turkana County?

\subsection{Scope of research}

The study examined educational outcome in both Turkana and Kiambu Counties. Results from Kenya Certificate of Secondary Education examinations were used. Socioeconomic factors of the two counties were examined to determine how they influence educational outcome.

\subsection{Significance of the study}

It is hoped that the research findings would be of importance to ministry of education, policy makers and the general public. The government and other policy makers will be able to discover barriers against quality educational outcome and therefore come up with policies and frameworks for mitigating the same.

\section{Review of Related Literature \\ 2.1 Introduction}

Poverty is a disastrous blow to a child's current live and the future. Poverty can be a product or result of failed social policies, poor education, inadequate policies, environmental related factors, chronic retrogressive cultural related factors or factors related to geographical determinism. Poverty can be classified either as absolute poverty (lack of food, housing, shelter or finance), to relative poverty (feeling poor compared to your neighbors), and generational poverty (long-term familial or community based or situational (temporary economic disaster) poverty though here we'll focus on the long-term. Some scholars, theorists and economists have accused the poor of causing their poverty. Others have accused them of living in the present and having no concern about tomorrow. Investing in education of children is investing for their future. But are the poor a failure in getting out of poverty through education? The government of Kenya introduced Free Primary Education (FPE) in 2002 and ten years later, partially Free Secondary Education was actualized. The primary objective was to ensure equitable access to quality basic education by all school going children in Kenya. By 2018, the government reported $95 \%$ transition of learners from primary to secondary and a very successful FPE and partially free secondary education. However, from the information provided in tables 4, 5 and 6 , it is evident that despite the efforts made through five decades down the line and more so in the last one decade, educational outcome in the poverty tormented areas are still extremely poor as compared to schools in wealthy areas. This study addressed the influence of generational poverty on educational outcome - from three perspectives; the learner, the school and the surrounding community.

\subsection{The Learner}

Psychosocial and psychological processes are sensitive components in every child and if interfered with, will have far reaching consequences in the overall development of the child. Worst still, on the cognitive development which has direct influence on educational outcome.

\subsubsection{The Effects of Poverty on the Brain (Cognitive development)}

The effects of generational poverty on any human child can cause live-long devastating effect. Areas of the brain that are affected by chronic exposure to poverty include those responsible for working memory, impulse regulation, Visio-spatial, language and cognitive conflict (Noble, et al. 2005). Among key distracters are chronic stress, chronic exposure to substandard cognitive skills and impaired emotional-social relationships. While not every single child will experience all of these factors, the majority will.

\subsubsection{Chronic Stress}

When compared to their middle-or upper-income classmates, more children from lower socioeconomic societies are more likely to be affected by stress as compared to those of middle or upper income? Poor families move twice as often, get evicted five times as much (Federman et al., 1996). Poor children have more contact with aggressive peers (Sinclair et al., 1994). They experience more community violence; from an unsafe home neighborhood or neighboring communities-which can hurt their academic performance (Schwartz \& Gorman, 2003). Inadequate safety concerns, leads to academic underperformance (Pratt et al., 1997).

Significantly more daily stresses--up to 35 percent, more daily hassles and the toll on the body adds up (Attar et al., 1994). Worse food choices affects appetite and eating habits becomes altered by chronically higher levels of cortical (Cartwright, et al., 2003).

\subsubsection{Cognitive Development}

There is considerable evidence that children from poverty are more likely to have impaired exposure to critical 
enrichment factors resulting in substandard cognitive skills. Here are some differences of those from poverty vs those in middle and upper income homes: Parents from poverty use different vocabulary words every day, both fewer and less complex than those heard in families of greater income (Hoff, 2003), Poor children are more likely to have parents that are less likely (by a factor of three or four) to initiate conversation just to maintain social contact or build vocabulary (Hart \& Risley, 1995). In affluent communities, children have more books in their homes than poor children have in all school sources combined (Korat, \& Haglili 2007). Poor parents are only half as likely to read to their kids as compared to high-income children (Coley, 2002). Have lower quality of nutritional intake in low-income infants and toddlers which is linked to lower cognition (Frank et al., 1995).

These issues are relevant because, for example, while children from poverty typically have cognitive deficits, they can be improved with specific skill-building programs in reading, writing, math and problem-solving. In regard to emotional-social relationships, children from affluent families, right from birth, experience formation of a secure attachment between parent and child which creates the baseline strengths and coping skills which will set in motion the quality of future relationships with teachers and peers (Szewczyk-Sokolowsky and Bost, 2005).

Unfortunately, children from poverty are far less likely to get the baseline of a solid, strong two-parent family and the resulting parental support. Poor children experienced less parental support and are parented in a less responsive, more authoritarian, harsher fashion than their higher income counterparts (Evans, 2004). Poor children feel that their parents are not very interested in their activities and, as a result are less open to their parents about their feelings (Rosenfeld, Richman and Bowen, 1998) and They develop fewer social ties and have more chaos, stress, and disruption in their lives (Jensen et al., 1983).

The foregoing experiences can affect self-esteem and even influence their everyday live and choice of those whom they'd like to have as friends. Chronic stress is a key factor and it increases likelihood of inappropriate attachments (Schore, 2002). This creates a vicious cycle where poor kids lack the grounded strong quality home relationships, yet, they are more likely to seek the wrong ones at school. Good relationships lower stress, provide guidance and support.

\subsection{THE SCHOOL}

In any school setting, there are three aspects that are crucial for realization of optimal educational outcome; -

a. School facilities (structures, furniture and recreational facilities ),

b. Instructional resources (teaching/learning materials) and

c. qualified human resource (teachers and administrators )

\subsubsection{School Facilities}

Facilities basically refers to long term fixed and non fixed structures and or objects. The most basic include but not limited to tutorial rooms (classrooms), Administration rooms, Experimental and demonstration rooms (laboratories and workshops), furniture, health facility, recreational facilities (play grounds, swimming pools). The tutorial rooms should be appropriate for the purpose intended for, spacious enough for the target group and safe enough in terms of ventilation, lights and from effects of adverse weather. The furniture should be of appropriate size and design for the particular targeted age of learners. The critical importance of recreational facilities (play grounds, swimming pools etc ) need no emphasis.

\subsubsection{Instructional Resources (teaching/learning resources)}

Instructional resources comprise course books, revision books, referent books, laboratory equipment, writing materials, equipped library (print and non print) and other supporting resources like projectors and power points. These materials and equipments serve as the most essential tools of work; without which effective teaching/learning might not occur.

When free secondary education began in January 2008, the Government set aside Kshs. 10,265 per annum for each student in a public secondary school. This was in addition to funding tuition, teaching and learning materials as well as meeting the cost of salaries for teachers and wages for non-teaching staff. Parents were to meet the cost of school meals for day-scholars, school uniforms, cost of providing structures and boarding fees at Kshs. 18,627 per annum. In the urban slums, arid and semi-arid areas, the Government continues to supplement efforts by parents in managing low-cost boarding schools and the school-feeding program. By introducing free secondary education, the government aimed at eliminating obstacles that hitherto blocked some students from pursuing secondary education. The governments aims at ensuring $100 \%$ transition of pupils from primary to secondary education, hence enhance acquisition of literacy and skills as an approach to eradicating poverty. While this noble aim may have been relatively achieved in some parts of the country, Turkana County is still far from it

\section{2,3.3 Service Delivery}

The practice in Kenya is that teachers are trained by ministry of education in Teacher Training Colleges (for the case of primary school teachers) and at the university level for secondary schools and training institutions. Teachers are recruited, posted and supervised by Teachers Service Commission (TSC)- as a government agency charged with the responsibility of managing teacher services in the country. Other functions include assigning teachers employed by the commission for service in any public school in Kenya, review standards of education and training 
of persons entering teaching service, promote and transfer teachers. According to TSC, Turkana County is the fourth most understaffed counties in the country.

Kay Ann Taylor, a professor of education at Kansas State University, asserts that because teachers are not trained to work specifically in poor zones and generally lack a background for comprehending the culture of poverty, their efforts in the classroom are obstructed. Additionally, educators from kindergarten to college use textbooks that do not address poverty and tend to lionize high grades and white color jobs while relegating lower grades and the poor to the margins (L-T\&A09Capra.qxp:Layout 1 ).

In regard to how to work among the poor, Taylor suggests that teacher preparation programs, including graduate degrees, should require courses that provide an overview of poverty and methods of working with this population. She suggested that fellows can be tapped from various professions including law, finance, medicine, and sales (mostly individuals wishing to make a career change) and taken through purposive poverty elevation courses. Candidates who complete this program are exposed to the realities of teaching in impoverished communities before they enter the classroom. In deed traditional teacher preparation programs could easily replicate this model by requiring pre-service teaching, or at least intense observation in economically disadvantaged areas. Additionally, course work that explicitly explores the relationship between socioeconomic factors and learning will better prepare teacher trainees for the challenges of working among the poor.

\subsection{THE ENVIRONMENT}

This study looked at the influence of three components of the environment: geographical, socio-economic and socio-cultural and how they influence educational outcome.

\subsubsection{Geographical component}

Agriculture is the backbone of Kenya's economy. About three quarters of Kenyans rely on agriculture not just for food but also as a source of income. In the rural areas, majority of the people are engaged in farms either growing crops (either cash crops or for consumption ) or keeping livestock. Some are engaged in businesses related to farming. They serve either as middle men connecting the farmers to available markets or as the market themselves (consumers ).Many agricultural-based industries have been established. However, with inconsistent weather and long droughts, agricultural activities have been hampered with-thus leading to diminished returns from agricultural sector.

For example, in most parts of Northern Kenya, environmental challenges - including erosion, desertification, drought and water shortages - have caused detrimental impacts on food security. Turkana County and its environs is one of those regions that has -for decades, affected sensuously by erratic and inconsistent weather, thus occasioning generational poverty in the region.

\subsubsection{Socio-economic component}

One of the Sustainable Development Goals (SDG) developed in 2016, aims at eliminating hunger by the year 2030. Unfortunately, hunger and malnutrition remains a large obstacle on the path to achieving this noble goal and development in general in many countries in Africa.

Reports indicate that one-third of the population of Eastern Africa is undernourished (FAO, 2017). Food insecurity and hunger are caused by many factors, often being intertwined with one another. In general, the principal causes of hunger include poverty, conflict, climate and weather, lack of investment in agriculture, and unstable markets. (World Food Programme, 2018).

Individuals living in poverty often cannot afford food of sufficient quality or quantity to live a healthy life. According to the World Bank, in 2013, 42.3\% of the population of sub-Saharan Africa lived on $\$ 1.90$ or less per day, a principal factor of widespread hunger. Poverty is often a cycle. Children exposed to long-term undernutrition are often stunted, leading to long- term consequences including decreased labor productivity and incomeearning potential (FAO, 2017)

In regard to education, most families find themselves unable to raise school fees for their children. As a result, majority of the children are unable to attain secondary education. School drop-out, early pregnancies, early marriages, resorting to family cores, are common phenomena.

\subsubsection{Conflicts and Tribal Animosity}

Conflict and violence can have direct and indirect impacts on all levels of the food system, leading to food insecurity and hunger. Conflict often puts constraints on employment and income opportunities, which affects an individual's ability to acquire food. Conflict can also affect exports and imports, which can lead to limited food availability and affordability. Availability of food can also be affected if resources (land, equipment, etc.) used to produce food are destroyed during times of conflict or by erratic weather conditions (FAO, 2017). Conflict over scarce resources is a common phenomena among poor communities-specially those living in arid and semi arid lands. The conflict range from tribal animosity, cattle rustling, quarrels over pasture and water sources.

\subsubsection{Socio-cultural component}

According toVygotsky's socio-cultural theory, culture affects children's cognitive development in a number of ways. Culture affects children cognitive development by shaping their perception of the world and the way they 
interpret and interact with it. The community teach their children cognitive tools that "not only equip children with specific ways of interpreting and handling experience but also survival and self defense skills useful during difficulties. (Ormrod, 2014). Studies have shown that sustained exposure to a set of cultural experiences and behavioral practices will affect neural structure and function. That the burgeoning field of cultural psychology has often demonstrated the subtle differences in the way individuals process information-differences that appear to be a product of cultural experiences (Park and Huang, 2010).

\section{CHAPTER THREE: METHODOLOGY}

\subsection{Research Design}

The design used was majorly descriptive survey research, using both qualitative and quantitative approaches. The secondary data was gathered from published reports and bulletins as per the literature highlighted in the second chapter of this report and it helped in collection of primary data. The main method used in data collection was by use of questionnaires, interviews and focused group discussions.

\subsection{Study population}

The study was based on the performance form fours at Kenya Certificate of Secondary Education (K.C.S.E) Turkana and Kiambu Counties. The duration covered the years 2015-2018. K.C.S.E performance was chosen as a standard measure in performance between the two counties because it is a national exam and therefore not biased. In addition, members of the public in the two counties, County executives, administrators, policy makers, project coordinators and supervisors were interviewed.

\subsection{Sample size and Sampling procedure}

Purposive sampling technique was used. The respondents targeted were those believed to have reliable information sort by the study. In regard to educational performance, the best top ten schools in academic performance were used as sample for the study. Other participants were executives and administrators of the county government, NGOs and members of the public.

\subsection{Research instruments}

Structured questionnaires and interview guides were the main research instruments used to collect data. However, documentary analysis and focused group discussions were also conducted.

\subsection{Validity and reliability}

In order to ensure the validity of the instrument and the procedure, an advice was sort from experts. The experts were to ascertain or otherwise advice so as to ensure that the research instruments were accurate, correct, true and meaningful. After their judgment on each item, adjustments were made based on their advice. The data collection tools were pretested through a pilot study before they were put into use. Errors and other necessary adjustments were corrected before the study commenced. Thereafter final instruments were produced for data collection.

\subsection{Data gathering procedure}

As indicated before, performance records for all the schools were obtained from the county educational offices. These are records compiled by education officers and are believed to be reliable. The questionnaires were administered to teachers and head teachers of the selected secondary schools, officials of county governments, officials of various NGOs operating in the area of study and members of the public. Executives of the county government, administrators, leaders of different churches, NGOs and other groupings were interviewed.

\subsection{Data analysis}

After all the data had been assembled, questionnaires that had many unfilled parts or errors were excluded in the analysis. Data from interviews, and group discussions were summarized. All the data collected were triangulated, analyzed and summarized. The findings were described using tables, percentages and bar graphs.

\subsection{Limitation of the study}

The study was conducted in two counties out of a total of forty seven counties. The counties chosen were those at the extreme ends. These were Turkana County (The county with the highest poverty level in the country) and Kiambu County (The county with the lowest poverty level in the country). The other forty five counties are in between the two in terms of socioeconomic strength.

\section{Chapter four}

Data Analysis, Presentation and Discussion

This chapter presents the findings of the study, analysis and discussion. The findings are presented in line with the 
research objectives.

\subsection{Research Findings}

The first objective of the study was to determine how poverty influence educational outcome in Turkana County. After analysis of the research findings, it became apparent that Turkana County has been performing poorly in KCSE over the years. Enrolment at secondary level is extremely low. The cause of the poor performance revolves around poverty. The rate of poverty in Turkana County is $87.5 \%$ (Table 3 ). This implies that out of 100 people, 87 of them are poor. Majority of the parents cannot afford a meal on daily basis leave alone the cost of secondary education for their children. The study established that most primary schools in the county are supported by NGOs like World Vision and both county government and the national government through school feeding programme. The impact of this support is high enrolment in both pre-school and the primary level. Although the government launched free secondary education, it is not absolutely free as such. There is a certain amount of cost to be met by the parent. However, due to the high poverty level, most parents cannot afford it. This explains why there is a sharp drop in the transition from primary to secondary. Figure 1 show the percentage comparison of transition trends of Turkana County in comparison to national transition trends.

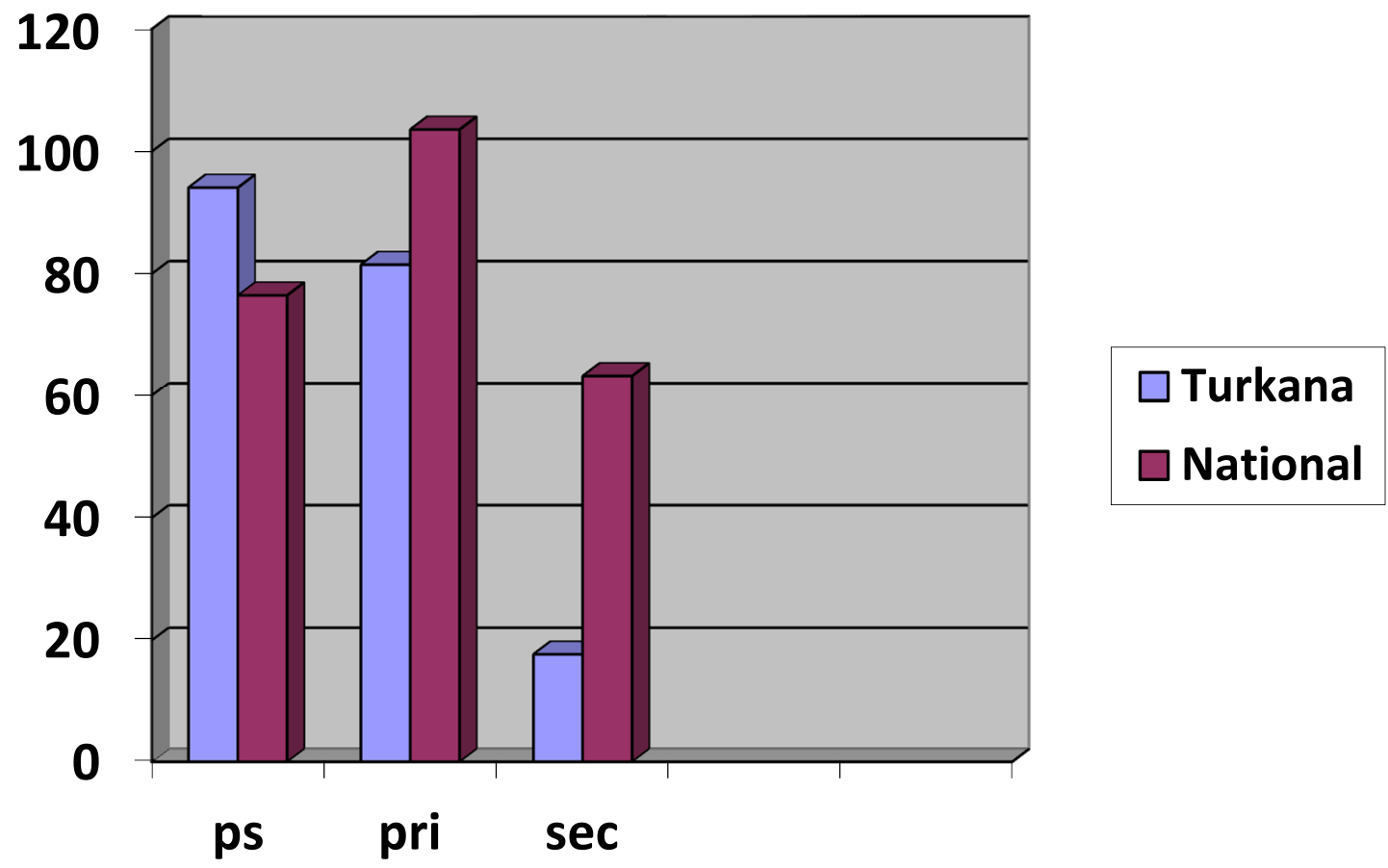

Figure 6: Transition trends : Turkana County compared to National

Figure 6 show that enrolment at pre-school (ps) is very high (94.1\%) compared to national enrolment at $76.5 \%$. When pupils proceed to primary (pri), enrolment dropped to $81.5 \%$ while at the national, it shot up to $103.6 \%$. The national enrolment rose beyond $100 \%$ as a result of some adults (commonly referred to as mature or over age students) enrolling for primary education following introduction of free primary education. The ugly part of it about Turkana County is the extremely low percentage of pupils pursuing secondary education, a drop from $81.5 \%$ to $17.7 \%$. It is expected that with free secondary education and the government emphasis for $100 \%$ transition from primary to secondary, the drop should have been minimal. It is no doubt the cause of this extremely low transition from primary to secondary revolves around poverty-as described in the previous chapters.

Data collected from documentary analysis and interviews showed that the county has been undergoing numerous challenges over decades. The most hurting are long droughts every year and cattle rustling and other forms of animosity with their neighboring communities. To worsen the situation, almost the entire county is an arid land. Being a pastoral community, the main economic activity has been herding. With long perennial droughts, this sector was severely affected. As a result, majority of Turkana residents suffered generational hunger due to lack of adequate quality food and clean water. Majority of the locals for the better part of each year suffer starvation and their bodies are ever emaciated. Absolute poverty became part of everyday live among Turkana residents.

With absolute poverty, little can be done on development leave alone investing. Education was equally affected. Most families could not afford school fees and other levies incurred to sustain a student in school. Many considered education a secondary need as they concentrated on basic needs ( food, water, clothing and security ) 
for survival. Most children are psychologically and socio-cognitively impaired. Schooling and school performance are adversely affected. As stated in the previous chapters, poverty affects the psychosocial and psychological processes -yet these are sensitive components in every child and if interfered with, will have far reaching consequences in the overall development of the child. The findings of the current study are in conformity with the research findings of Noble, et al. ( 2005 ) who noted that the effects of generational poverty on any human child can cause live-long devastating effect. Areas of the brain that are affected by chronic exposure to poverty include those responsible for working memory, impulse regulation, visio-spatial, language and cognitive development. Noble observed that the key distracters are chronic stress, chronic exposure to substandard cognitive skills and impaired emotional-social relationships. These are among the factors behind poor KCSE performance in Turkana County as compared to KCSE performance in Kiambu County. However, while not every single child in Turkana County experience all of these factors, the majority do. The few who manage to score good grades in KCSE and proceed to university or get employment, often prefer to work and live in towns. It is obvious that when the educated, energetic and working class of a community prefer living away from their very origin, it dashes away the perceived hopes and expectations of not only the parents but also the local community.

\subsection{Research Objective Two}

The second objective of the study was to establish the major causes of poverty in Turkana County.

Analysis of the data collected show that the cause of poverty in Turkana County is a three- fold chronic problem notably: erratic perennial weather couple with climatic conditions, Chronic insecurity and "economic derailment".

\subsubsection{Erratic Weather}

Turkana County is a vast dry land of approximately $68,680 \mathrm{sq} \mathrm{km} \mathrm{(26,520} \mathrm{sq} \mathrm{miles} \mathrm{).} \mathrm{The} \mathrm{entire} \mathrm{region} \mathrm{experience}$ erratic weather and long droughts for the better part of the year,- a situation that has been persistent for some decades. The residents of Turkana County are mainly Turkana community- a sub-tribe of Plain Nilotes of Kenya. Just like all other Plain Nilotes, Turkana people keep indigenous livestock as their main source of livelihood. Due to unreliable rainfall and long droughts, they keep moving from one place to another in such of pasture and water for their livestock. According to some interviewees, hundreds if not thousands of livestock die every year due to disease and lack of pasture and water.

\subsubsection{Insecurity}

Cattle rustling and banditry is another chronic problem that has pushed Turkana people to a state of perpetual poverty. The study established that thousands of livestock are lost every year to armed bandits from neighboring communities. During these attacks, lives and valuable properties are lost as well. Some of the damages experienced during the conflicts include destruction of structures ( houses), business premises and looting of valuable items. Most of the local residents interviewed reported that one of the worst experience they usually encounter during these conflicts is merciless killing of persons including women and children. Frequent movements and resettling in different places in search of safety is a common phenomena.

\subsubsection{Economic derailment}

The study established that Turkana County lack behind in terms of development. The term "development" is used here to refer to the level and quality of infrastructure and social services available in the county in comparison to other counties in the country. This might have been contributed by other compounding factors like level of poverty index, climatic conditions vis-a -vi land productivity, geographic determinism and either lack of or unimplemented development policies. However, with devolution since 2013 and with discovery of oil reservoirs and subsequent drilling of the same, Turkana County is on the path of progression. The county has not just opened up but has attracted investors and huge investment projects from both the government and private entities. Given the adverse effects inflicted on the people of Turkana County by the foregoing, there is no reason to doubt as to why educational outcome in Turkana County remained below average for decades.

Previous studies alluded that, Emotional and Social Challenges, Acute and Chronic Stressors, Cognitive Lags, Health and Safety Issues- all combined, present an extraordinary challenge to academic and social success.That children require healthy learning and exploration for optimal brain development. Unfortunately, in an hostile environment and impoverished families there tends to be a higher prevalence of such adverse factors as teen motherhood, depression, and inadequate health care, all of which lead to decreased sensitivity toward the infant (van Ijzendoorn et al., 2004) and, later, poor school performance and behavior on the child's part.

The findings of the current study are in conformity with earlier research findings that students raised in poverty are especially subject to stressors that undermine school behavior and performance. For example, girls exposed to abuse tend to experience mood swings in school, while boys experience impairments in curiosity, learning, and memory (Fergason et al, 2007). The stress resulting from transience-frequent short-distance, poverty-related movements (Schafft, 2006) - also impairs students' ability to succeed in school and engage in positive social interactions. Whereas middle-class families usually move for social or economic improvement, the moves of low-income households are typically not voluntary. In addition to increasing children's uncertainty about the future, these moves compound their stress load by disrupting their social interactions both within the 
community and in academic environments (Levin, 2007).

Students who have to worry over safety concerns also tend to underperform academically (Pratt, Tallis, \& Eysenck, 1997). Exposure to community violence — an unsafe home neighborhood or a dangerous path to schoolcontributes to lower academic performance (Schwartz \& Gorman, 2003). On the other hand, children brought up in affluent families and in developed environment ( as for the case of Kiambu County ) then to perform relatively well in the education ( Table 2).

\subsection{Research objective Three}

The third research objective was to determine the mechanism put in place to alleviate poverty in the most affected parts of the country of which Turkana County is one of them.

Practical policies in fighting poverty became eminent with the launching of The National Poverty Eradication Plan (NPEP) 1999-2015 and The Poverty Reduction Strategy Paper (PRSP) 2000-2003. NPEP was launched in 1999 as a result of failure to combat poverty through national development plans and poverty-specific programmes. The aim of NPEP was to provide a national policy and institutional framework for action against poverty (Omiti et.al., 2002). However, a decade later, there were no much improvement in reducing poverty rate in the most affected areas. According to Kenya Population and Housing Census of 2009, the level of poverty in Turkana County was still the highest compared to other counties. Table eight provides a summary of some basic information about Turkana County compared to Kiambu County

Table 10: Poverty rate in Turkana and Kiambu Counties

\begin{tabular}{|l|l|l|}
\hline Item & Turkana County & Kiambu County \\
\hline Total population & 855,399 & $1,623,282$ \\
\hline Total area in sq km & 68,680 & 2543 \\
\hline Population density per sq km & 13 & 638 \\
\hline Poverty rate & $94.3 \%$ & $27.2 \%$ \\
\hline
\end{tabular}

Source : Commission on Revenue Allocation (2011)

From the above table, out of every 100 people in Turkana County, 94 of them are poor. Definitely, this is an extreme case of poverty. The Commission on Revenue Allocation came up with what was termed access to infrastructure under the title: "Kenya Counties Fact Sheet 2011". This provided a summary of further basic information about each county. Provided below is a summary of their findings about Turkana and Kiambu counties-compared.

Table 11: Infrastructure

\begin{tabular}{|l|l|l|}
\hline Item & Turkana County & Kiambu County \\
\hline Access to improved water & $74.3 \%$ & $78.1 \%$ \\
\hline Improved sanitation & $17.8 \%$ & $99.6 \%$ \\
\hline Access to Electricity & $2.4 \%$ & $53.0 \%$ \\
\hline Paved roads & $9.3 \%$ & $16.0 \%$ \\
\hline Good/fair roads (\% of total roads) & $59.5 \%$ & $44.8 \%$ \\
\hline Can read and write & $18.1 \%$ & $87.4 \%$ \\
\hline Attending school (15-18 years ) & $9.5 \%$ & $70.1 \%$ \\
\hline
\end{tabular}

Source : Commission on Revenue Allocation (2011)

The table above provides shows that Kiambu County is far a head of Turkana County in terms of infrastructure. Upon devolution in 2013 and in an attempt to address the socioeconomic challenges in their county, Turkana County government came up with what they referred to as County Integrated Development Plan (CIDP) 20132017. The purpose of CIDP is to provide an overall framework for development in the county. It's focus is on economic and social development and it aims at co-coordinating the work of the local and other spheres of government coherent plan in order to improve the quality of life for all the people living in Turkana County. Through CIDP, Turkana County government identified eight key developmental targets to be executed within the specified five period of time. The eight targets referred to as Flagship Projects were as follows;

i. To tarmac the key national roads joining the county and the rest of the country,

ii. Establish international airport at Lodwar,

iii. Promote tourism in Turkana County and institutionalization of county annual cultural bonanza,

iv. Modernization of urban towns and complete with essential social services and amenities,

v. Increase energy access and improve uptake of green energy through investing in geothermal and solar energy generation,

vi. Establish Turkana skill development and support fund to meet human resource needs and capacities for social and economic development of the county,

vii. Provide sufficient calorific requirements for over a million residents of Turkana,

viii. Own, design and operationalize utilization of the discovered aquifers in the county for increased 
productivity for commercial and domestic use

The foregoing are crucial development key pointers providing a clear roadmap that would see Turkana County emerge out of poverty. The question is how much have been achieved so far?

ACHIEVEMENTS

It is evident that through the CIDP, the National Government and other partners, a lot has been achieved in Turkana County.

(a) In terms of infrastructure, the length of road under bitumen has been extended from $300 \mathrm{~km}$ as contained in KPHC(2009) to $488.5 \mathrm{~km}$ ( CIDP 2013-2017). Secondly, In addition to the Lokichogio airport, the county has a tarmac airstrip at Lodwar and 21 other airstrip already leveled but yet to be put under tarmac.

(b) Concerning education, the current study found out that the number of primary schools has gone up from 202 in 2009 to 315 by 2018. Within the same period of time, the number of secondary schools has increased from 33 to 43 schools presenting candidates for KCSE as at 2018. In addition, there are two polytechnics namely Kakuma women Home Craft and Lodwar Youth Polytechnic. The county has two colleges - Kenya Medical Training College and Early Childhood Development Teachers Training College and two university campuses. The Ministry of Education through the Economic Stimulus Programme, is constructing a Technical Training College at Lodwar.

(c) On energy access, Lokori, Lokitaung and Lokichogio power generation projects stand at $80 \%$ completion (CIDP). Kainuk centre is already connected to Hydro-Electric power from the national grid. Otherwise all the other towns and institutions still rely on diesel power generators and solar panels.

(d) On food security, already 2458 hectares of land is under irrigation.

With all these developments in progress, there is no doubt, Turkana County is on the path to prosperity though at a slow phase. Efforts to alleviate poverty in Turkana County has attracted the attention of several NGOs. Most of the NGOs undertake projects - mainly on food, security and health. They include World Food Prgramme (WFP), United Nations Children's Fund (UNICEF), World Vision, Oxfam GB, Medical Relief International, International Rescue Committee ( IRC), Lutheran World Federation(LWF), United Nations High Commission for Refugees (UNHCR), Food and Agriculture Organization(FAO), Veterinares Sans FrontiersBelgium, among others.

With all the effort made by Turkana County Government, The National Government and NGOs, the level of poverty in Turkana County will be alleviated. In the long run, the negative effects of poverty on all levels of school success will be prevented or reversed.

\section{Conclusion}

\subsection{Research Objective One}

The first objective of the study was to determine how poverty influence educational outcome in Turkana County. After analysis of the research findings, the study concludes that the consistent poor performance in KCSE over the years in Turkana County is as a result of chronic poverty. Enrolment at secondary level is extremely because adolescence (with influence of their parents) opt to look for survival means rather than education. Their daily preference is to get what to eat, water and safety. School going children often experiment frequent absenteeism from school while some drop out of school. These among others as explained in the previous pages, are the reasons behind low school enrolment and poor performance.

\subsection{Research Objective Two}

The second objective of the study was to establish the major causes of poverty in Turkana County.

After analyzing the data, the study concludes that the cause of poverty in Turkana County is erratic perennial weather couple with climatic conditions, Chronic insecurity and 'economic derailment'. Most agricultural activities are no longer tenable. Rains are no longer reliable. The region experience short rains followed by long duration of drought. Cattle rustling has rendered many families to extreme poverty levels. Accessing health care, clean water, markets among others, is a big problem due lack of development.

\subsection{Research Objective Three}

The third research objective was to determine the mechanism put in place to alleviate poverty in the most affected parts of the country of which Turkana County is one of them. The study concludes that although the level of poverty is still extreme in some parts of the country, among them Turkana County, a lot of effort is going on to alleviate it. The national government, the county government and Non Governmental Organization are making a lot of effort to improve the lives of people living in Turkana County along with other regions. 


\section{REFERENCES}

Attar, B.K., Guerra, N.G. and Tolan, P.H., (1994) Neighborhood disadvantage, stressful life events, and adjustment in urban elementary-school children. Journal Clin Child Psychol 23, pp. 391-400.

Rosenfeld, L. B., Richman, J. M., \& Bowen, G. L. (1998). Low social support among at-risk adolescents. Social Work In Education, 20, 245-260.

Bradley, R. H., \& Corwyn, R. F. (2002) Socioeconomic status and child development. Annual Review of Psychology, Annual, 371-400.

Cartright, M., Wardle, J., Steggle, N. (2003). Stress and dietary Practices in adolescence. Health Psychology, vol 22(4)

Coley, D. \& Richard, J. (2002). An Uneven Start: Indicators in School Readiness-ETS Policy Information Centre.

Evans, G. (2004) the Environment of Childhood Poverty. American Psychologist. February/March, Vol. 59, No. 2, 77-92.

Federman, M., Garner, T., Short, K. Cutter, W., Levine, D., McGough, D. and McMillin, M. (1996). What does it mean to be poor in America? Monthly Labor Review, 3-17

Frank, L., Willet, B.J. and Murname, R. (1995). The growing importance of Cognitve Skills in Wage Determination, MIT Press.

Hart, B., \& Risley, T. R. (1995) Meaningful Differences in the everyday Experiences of Young American Children. Baltimore, MD, Paul H. Brookes Publishing.

Hoff, D. (2003) The specificity of environmental: Socioeconomic status affects early vocabulary development via maternal speech. Atlantiv University Press.

Jensen, E., James, S., Boyce, T. and Hartnett, S. (1983). The Family Routine Inventory: Development and Validation. Social Science and Medicine, 17, 201-211.

Korat, O. and Haglili, S. (2007) Maternal Evaluation of Children's Emergency Literacy. SAGE Journals.

Noble KG, Norman MF, Farah MJ (2005) Neurocognitive correlates of socioeconomic status in kindergarten children. Dev Sci Jan;8(1):74-87.

Pratt P, Tallis F, and Eysenck M.(1997). Information-processing, storage characteristics and worry. Behav Res Ther. 1997 Nov;35(11):1015-23.

FAO, IFAD, UNICEF, WFP and WHO. 2018. The State of Food Security and Nutrition in the World 2018: Building climate resilience for food security and nutrition. Rome, FAO. Retrieved from http://www.fao.org/state-of-food-security-nutrition/. Accessed September 15, 2018

FAO, IFAD, UNICEF, WFP and WHO. 2017. The State of Food Security and Nutrition in the World 2017. Building resilience for peace and food security. Rome, FAO. Retrieved from http://www.fao.org/3/aI7695e.pdf. Accessed September 5, 2018

Ormrod, J.E. (2014). Educational psychology: Developing learners (8th ed.). Upper Saddle River, N.J.: Merrill.

Park, D.C., Huang, C.M. (2010) Culture wires the brain: A cognitive neuroscience perspective. Perspectives on Psychological Science 5(4): 391-400. Retrieved fromhttp://www.ncbi.nlm.nih.gov/pmc/articles/PMC3409833

Schwartz, D. \$ Gorman, A.H. (2003). Community violence exposure and children's academic functioning. Journal of Educational Psychology.95(1)

Sinclair, R., Garnett, L. and Berridge, D. (1995) Social work and assessment of children in need. A report to Department of Health National Children Bureau.

Ferguson B, Tilleczek K, Boydell K, Rummens A, Roth Edney D. Early school leavers: Understanding the lived reality of student disengagement from secondary school - Final report. < http://www.edu.gov.on.ca/eng/policyfunding/reports.htm $>$ (Version current at September 10, 2007)

Levin B. Educational responses to poverty. < http://www.csse.ca/CJE/Articles/FullText/CJE20-2/CJE20-209Levin.pdf $>$ (Version current at September 10, 2007) 